\title{
ANALISIS FINANSIAL PEMANFAATAN TONGKOL JAGUNG DENGAN FERMENTASI BIOAKTIVATOR Starbio, Aspergillus niger dan Trichoderma viride DALAM RANSUM DOMBA JANTAN LOKAL LEPAS SAPIH
}

\author{
(Financial Analysis of Utilization of Corn Cob With Bioactivator Starbio \\ Fermentation, Aspergillus Niger and Trichoderma viride in Ration to the Weaning \\ Males Local Sheep)
}

\author{
Rony Alviansyah ${ }^{1}$, Hasnudi $^{2}$ dan Tri Hesti Wahyuni ${ }^{2}$
}

1. Mahasiswa Program Studi Peternakan Fakultas Pertanian Universitas Sumatera Utara

2. Staff Pengajar Program Studi Peternakan Fakultas Pertanian Universitas Sumatera Utara

\begin{abstract}
The experiment was conducted at the Laboratory of Animal Biology, Animal Husbandry Study Program, Faculty of Agriculture, University of Sumatra Utara started from August to September 2013. This study aims to determine the business value of the use of corn cob on a weaning males local sheep. The research used 20 local sheep with an average initial body weight 8,6 $\pm 1,13 \mathrm{~kg} / \mathrm{head}$ and divided into four treatments and five replications. The treatment in this study were P0 : without fermented corn cob, P1: fermented corn cob starbio 0,5\%, P2: Aspergillus niger fermented corn cob 0,5\%, P3: Trichoderma viride fermented of corn cobs 0,5\%, P4: Aspergillus niger fermented corn cobs 0,25\% and 0,25\% Trichoderma viride. The variables were used in this study composed of the Total Cost, Total Revenue, Profit and loss analysis, revenue cost ratio ( $R / C$ ratio ) and income over feed cost (IOFC). The results showed that the highest income on treatment P1 (Rp 107.382,68/head/2months) and the lowest was the P0 (Rp 6.813,72/head/2months). The highest revenue cost ratio( $R / C)$ were $P 1(1,22)$ and the lowest in the P0 (1,01). While income over feed cost(IOFC) highest on the treatment of P1 (Rp160.582,68/head/2months) and lowest at P0 treatment (Rp. 47.545,62/head/2months). The conclusion of this study is the use of corn cobs with bio-activator starbio in feed of weaning sheep feasible to be applied in the weaning sheep.
\end{abstract}

Keywords: Financial Analysis, Corn Cobs, The Weaning Males Local Sheep, Bio-activator

\begin{abstract}
ABSTRAK
Penelitian ini bertujuan untuk mengetahui nilai usaha dari pemanfaatan tongkol jagung terhadap domba lokal jantan lepas sapih. Penelitian ini menggunakan 20 ekor domba dengan rataan bobot badan awal 8,6 $\pm 1,13$ dengan menggunakan metode survey. Perlakuan yang digunakan dalam penelitian ini adalah P0 (tongkol jagung tanpa fermentasi), P1 (tongkol jagung fermentasi starbio 0,5\%), P2 (tongkol jagung fermentasi Aspergillus niger 0,5\%), P3 (tongkol jagung fermentasi Trichoderma viride 0,5\%), P4 (tongkol jagung fermentasi Aspergillus niger 0,25\% dan Trichoderma viride 0,25\%). Parameter yang digunakan yaitu Total Biaya Produksi, Total Hasil Produksi, Analisis Laba-rugi, revenue cost ratio (R/C ratio) dan income over feed cost (IOFC). Hasil analisis laba-rugi tertinggi selama dua bulan adalah pada perlakuan P1 memberikan keuntungan Rp/ekor $(107.382,68)$ dan terendah adalah P0 Rp/ekor $(6.813,72)$. Rataan revenue cost ratio (R/C) tertinggi adalah P1 sebesar 1,19 dan terkecil pada perlakuan P0 sebesar 0,99. Rataan income over feed cost (IOFC) tertinggi pada perlakuan P1 sebesar 160.582,68 dan terendah pada perlakuan P0 sebesar 47.545,62. Kesimpulan dari penelitian ini adalah pemanfaatan tongkol jagung dengan bioaktivator starbio dalam pakan domba jantan lokal lepas sapih layak untuk di terapkan dalam usaha peternakan domba.
\end{abstract}

Kata Kunci : Analisis Finansial, Tongkol Jagung, Domba Jantan Lokal Lepas Sapih, Bioaktifator 


\section{PENDAHULUAN}

Seiring dengan meningkatnya populasi penduduk, kemajuan teknologi dan kasadaran masyarakat akan pentingnya gizi, maka kebutuhan akan protein hewani juga semakin meningkat. Untuk memenuhi kebutuhan protein hewani masyarakat maka peternak harus menguasai ekonomi peternakan agar menghasilkan ternak yang berkualitas serta keuntungan dari segi ekonomi. Menurut Suharno dan Nazaruddin (1994) gambaran mengenai usaha ternak yang memiliki prospek cerah dapat dilihat dari analisis usahanya. Analisis dapat juga memberikan informasi lengkap tentang modal yang diperlukan, penggunaan modal, besar biaya untuk bibit (bakalan), pakan dan kandang, lamanya modal kembali dan tingkat keuntungan yang diperoleh.

Usaha ternak domba yang di kelola masyarakat pedesaan secara umum masih merupakan usaha pola budidaya yang sifatnya sebagai tabungan, yang pengolahannya bersifat usaha campuran (diversifikasi) dan berperan mendukung ekonomi rumah tangga. Kondisi demikian memperlihatkan kecenderungan peternak memelihara ternak belum mempertimbangkan manajemen pengolahan sehingga optimalisasi sebagai sumber pendapatan keluarga belum tercapai. Manajemen usaha masih berbasis sumberdaya pakan yang tersedia di lokasi tanpa diikuti dengan upaya peningkatan mutunya, modal biaya rendah (Low External Input), bahkan dapat dinyatakan tanpa adanya biaya produksi (zero cost) (Priyanto et al., 2004).

Usaha ternak domba merupakan salah satu jenis usaha yang dapat mendukung pola usaha tani di pedesaan karena dapat memberikan pupuk kandang dan sebagai sumber keuangan untuk membeli kebutuhan pertanian atau untuk memenuhi kebutuhan rumah tangga yang mendadak. Usaha ternak domba juga sangat disenangi oleh petani peternak di pedesaan karena pemeliharaannya relatif mudah serta tidak memerlukan modal usaha yang besar. Penelitian ini diharapkan dapat memberikan informasi yang dibutuhkan sebagai acuan untuk para pengambil kebijakan, baik itu petani peternak sendiri ataupun pihak pemerintah dan para investor, dalam mengembangkan usaha ternak domba yang dapat meningkatkan pendapatan pada masyarakat petani peternak. Peternakan merupakan subsektor yang berperan sangat penting dalam penyediaan kebutuhan pangan khususnya kebutuhan protein hewani. Kebutuhan protein hewani terus 
meningkat seiring dengan pertambahan penduduk dan meningkatnya kesadaran masyarakat akan pentingnya zat gizi.

Lebih dari 90\% usaha peternakan domba di Indonesia merupakan usaha peternakan rakyat dengan skala usaha kepemilikan 2-5 ekor. Pada masa mendatang, diharapkan pergeseran skala tipe usaha peternakan rakyat kearah industri peternakan yang lebih besar skala kepemilikan dombanya.

Analisis usaha ternak domba merupakan kegiatan yang sangat penting bagi suatu ternak yang mempunyai prospek cerah yang dapat dilihat dari analisis usahanya. Berdasarkan data tersebut dapat diukur keuntungan usaha dan tersedianya dana riil untuk periode selanjutnya. Melalui usaha ini dapat dicari langkah pemecahan berbagai kendala yang dihadapi. Analisis dapat juga memberikan informasi lengkap tentang modal yang diperlukan, penggunaan modal, besar biaya untuk bibit (bakalan), ransum, kandang, lamanya modal kembali dengan tingkat keuntungan uang diperoleh. Pemanfaatan limbah pertanian sebagai bahan pakan ternak merupakan salah satu alternatif bijaksana dalam memenuhi kebutuhan nutrisi bagi ternak. Limbah pertanian sebagai bahan pakan selalu dikaitkan dengan harga yang murah dan kualitas yang rendah. Besaran pemanfaatan limbah sangat tergantung pada potensi limbah baik secara kuantitas maupun kualitas yang dapat dimanfaatkan.

Salah satu limbah pertanian yang belum dimaksimalkan adalah tongkol jagung. Berdasarkan data realisasi tanam, panen, dan target jagung yang diperoleh Dinas Pertanian Jumlah limbah tongkol jagung di Sumatera Utara pada bulan Januari 2014 sekitar 80.069,4 ton.Tongkol jagung merupakan limbah dari hasil panen tanaman jagung yang belum banyak dimanfaatkan dimasyarakat. Dari segi biaya tongkol jagung dapat di katakan relatif murah, namun bila di jadikan bahan pakan ternak bagi ternak kandungan gizi masih kurang baik. Untuk meningkatkan kandungan nutrisi tongkol jagung tersebut dapat di lakukan proses fermentasi dengan biaya yang lumayan murah dalam segi biaya fermentasi. Fermentasi merupakan proses penguraian unsur-unsur organik kompleks terutama karbohidrat untuk menghasilkan energi melalui reaksi enzim yang dihasilkan oleh mikroorganisme yang biasanya terjadi dalam keadaan aerob dan anaerob yang diiringi dengan pembebasan gas (Sarwono, 1996). 
Berdasarkan uraian diatas, peneliti tertarik untuk melakukan penelitian yang berjudul "Analisis Usaha Pemanfaatan Tongkol Jagung dengan Fermentasi Bioaktivator Starbio, Aspergillus niger dan Trichoderma viride pada Domba Jantan Lokal.

\section{BAHAN DAN METODE PENELITIAN}

\section{Tempat dan Waktu Penelitian}

Penelitian ini dilaksanakan di Laboratorium Biologi Ternak Program Studi Peternakan Fakultas Pertanian Universitas Sumatera Utara Medan. Berlangsung selama 3 bulan mulai bulan Juli sampai September 2013.

\section{Bahan dan Alat Penelitian}

Domba lokal jantan lepas sapih umur 6-8 bulan sebanyak 20 ekor dengan rataan bobot badan awal 8,6 $\pm 1,13 \mathrm{~kg}$. Bahan pakan yang diberikan terdiri atas: tongkol jagung dan bioaktivator sebagai fermentator serta konsentrat terdiri atas: dedak halus, bungkil kedelai, ultra mineral dan garam. Bahan pakan difermentasikan dengan Starbio, Aspergilus niger dan Trichoderma viride. Obat-obatan seperti obat cacing (Kalbazen), anti bloat untuk obat kembung, air minum, desinfektan (Rhodalon) dan obat tradisional.

Kandang terdiri atas kandang individu 20 unit dengan ukuran $1 \times 0,5 \mathrm{~m}^{2}$ beserta perlengkapannya, ember sebanyak 20 buah sebagai tempat pakan dan 20 buah tempat minum, timbangan untuk menimbang bobot hidup berkapasitas $150 \mathrm{~kg}$ dengan kepekaan 50 gr, timbangan berkapasitas $2 \mathrm{~kg}$ dengan kepekaan $10 \mathrm{gr}$ untuk menimbang pakan, terpal plastik untuk mencampur dan menjemur bahan pakan/konsentrat, goni plastik sebagai tempat pakan, alat penerangan, grinder untuk menggiling bahan pakan, alat tulis untuk mencatat data selama penelitian, alat pembersih kandang dan termometer untuk mengetahui suhu di dalam dan di luar kandang.

\section{Metode Penelitian}

Metode yang digunakan adalah metode survey deskriptif karena dalam pelaksanaannya meliputi data, analisis dan interpretasi tentang arti dan data yang di peroleh. Penelitian ini disusun sebagai penelitian induktif yakni mencari dan mengumpulkan data yang ada di lapangan dengan tujuan untuk mengetahui faktor-faktor, unsur-unsur bentuk, dan suatu sifat dari fenomena di masyarakat.

Adapun perlakuan yang diberikan adalah : 
$\mathrm{P}_{0}$ : Tongkol jagung tanpa fermentasi

$\mathrm{P}_{1}$ : Tongkol jagung fermentasi dengan starbio $0,5 \%$

$\mathrm{P}_{2}$ : Tongkol jagung fermentasi dengan Aspergillus niger 0,5\%

$\mathrm{P}_{3}$ : Tongkol jagung fermentasi dengan Trichoderma viride $0,5 \%$

$\mathrm{P}_{4}$ : Tongkol jagung fermentasi dengan Aspergillus niger 0,25\% dan Trichoderma viride $0,25 \%$

Pembuatan pakan komplit di lakukan dengan cara menghaluskan terlebih dahulu bahan pakan penyusun ransum untuk memperkecil partikel, kemudian bahan pakan tersebut ditimbang berdasarkan persentase dalam susunan ransum. Setelah itu bahan tersebut diaduk agar homogen, dan ditambahkan bioaktifator pada perlakuan masingmasing. Setelah tercampur secara merata dengan kelembaban $60 \%$, bahan dimasukkan kedalam karung goni yang dilapisi plastik agar kondisi anaerob dapat tercapai. Ikat karung goni kemudian difermentasi selama 7 hari.

\section{Parameter Penelitian}

Total Biaya Produksi

Total biaya produksi atau total pengeluaran yaitu biaya - biaya yang dikeluarkan untuk menghasilkan suatu produk yang diperoleh dengan cara menghitung: biaya pakan, biaya bibit, biaya obat-obatan, biaya tenaga kerja, biaya perlengkapan kandang dan biaya sewa kandang (Rasyaf, 1996).

Total Hasil Produksi

Total hasil produksi atau total penerimaan yaitu seluruh produk yang dihasilkan dalam kegiatan ekonomi yang diperoleh dengan cara menghitung harga jual domba dan penjualan kotoran domba (Budiono, 1990)

\section{Laba/Rugi}

Keuntungan adalah tujuan setiap usaha. Keuntungan dapat dicapai jika jumlah pendapatan yang diperoleh dari usaha tersebut lebih besar daripada jumlah pengeluarannya (Murtidjo, 1995). Keuntungan (laba) suatu usaha dapat diperoleh dengan cara :

$\mathrm{K}=\mathrm{TR}-\mathrm{TC}$

Ket : 
$\mathrm{K}$ = keuntungan

$\mathrm{TR}=$ total penerimaan

$\mathrm{TC}=$ total pengeluaran .

Income Over Feed Cost (IOFC)

Income Over Feef Cost (IOFC) diperoleh dengan cara menghitung selisih pendapatan usaha peternakan dikurangi dengan biaya ransum. Pendapatan merupakan perkalian antara produksi peternakan atau pertambahan bobot badan akibat perlakuan (dalam kg hidup) dengan harga jual. Sedangkan biaya ransum adalah biaya yang dikeluarkan untuk menghasilkan pertambahan bobot badan ternak (Prawirokusumo, 1990).

$\mathrm{IOFC}=(\mathrm{BB}$ Akhir $-\mathrm{BB}$ Awal $\mathrm{x}$ Harga Jual Per kg $)-(\mathrm{KR} \times \mathrm{HR})$

Ket : $\quad \mathrm{KR}=$ Konsumsi Ransum $(\mathrm{kg})$

$\mathrm{HR}=$ Harga Ransum $(\mathrm{Rp} / \mathrm{kg})$

Revenue cost ratio (R/C Ratio)

Revenue cost ratio adalah perbandingan antara penerimaan penjualan dengan biaya-biaya yang dikeluarkan selama pross produksi hingga menghasilkan produk Soekarwati (1995).

Total penerimaan penjualan produk

$$
R / C \text { Ratio }=\frac{\text { Total biaya }}{\text { Tot }}
$$

\section{HASIL DAN PEMBAHASAN}

Rekapitulasi hasil penelitian dapat dilihat pada Tabel 1.

Tabel 1. Rekapitulasi selama penelitian

\begin{tabular}{cccccc}
\hline \multirow{2}{*}{ Perlakuan } & \multicolumn{5}{c}{ Parameter } \\
\cline { 2 - 6 } & $\begin{array}{c}\text { Total biaya } \\
\text { Produksi }\end{array}$ & $\begin{array}{c}\text { Total hasil } \\
\text { produksi }\end{array}$ & $\begin{array}{c}\text { Laba/Rugi } \\
\text { (Rp) }\end{array}$ & IOFC (Rp) & R/C Ratio (\%) \\
\hline P0 & $540.336,28$ & 547.150 & $6.813,72$ & $47.545,62$ & 1.01 \\
P1 & $556.799,22$ & 676.550 & $119.750,78$ & $160.582,68$ & 1.22 \\
P2 & $576.918,39$ & 599.750 & $22.831,61$ & $63.563,51$ & 1.04 \\
P3 & $541.331,54$ & 575.950 & $34.618,46$ & $75.350,36$ & 1.06 \\
P4 & $591.495,15$ & 678.850 & $87.354,85$ & $128.086,75$ & 1.15 \\
\hline
\end{tabular}




\section{Total Biaya Produksi}

Biaya produksi tidak dapat dipisahkan dari proses produksi sebab biaya produksi merupakan masukan atau input dikalikan dengan harganya. Maka dapat dikatakan bahwa ongkos produksi adalah semua pengeluaran atau semua beban yang harus ditanggung oleh perusahaan untuk menghasilkan suatu jenis barang atau jasa yang siap untuk dipakai konsumen (Nuraini, 2003). Total biaya produksi atau total pengeluaran yaitu biaya biaya yang dikeluarkan untuk menghasilkan suatu produk yang diperoleh dengan cara menghitung: biaya pakan, biaya bibit, biaya obat-obatan, biaya tenaga kerja, biaya perlengkapan kandang dan biaya sewa kandang (Rasyaf, 1996). Total biaya produksi pemeliharaan domba jantan selama penelitian menunjukkan perbedaan dimana rataan total biaya produksi tertinggi terdapat pada P4 sebesar Rp. 591.495,15 dan yang terendah pada P0 sebesar Rp. 540.336,28. Perbedaan jumlah pengeluaran ini dikarenakan adanya perbedaan jumlah biaya yang harus dikeluarkan untuk pembelian bibit dan pakan sementara biaya obat-obatan sewa kandang peralatan dan tenaga kerja adalah sama. Hal ini seperti dinyatakan oleh Kadarsan (1995) yang menyatakan bahwa biaya adalah nilai dari semua korbanan ekonomis yang diperlukan yang tidak dapat dihindarkan, dan dapat diperkirakan dan dapat diukur untuk menghasilkan suatu output. Pengeluaran perusahaan adalah semua uang yang dikeluarkan sebagai biaya produksi.

\section{Total Hasil Produksi}

Total hasil produksi atau total penerimaan yaitu seluruh produk yang dihasilkan dalam kegiatan ekonomi yang diperoleh dengan cara menghitung harga jual domba dan penjualan kotoran domba. total hasil produksi pemeliharaan domba jantan selama penelitian menunjukkan perbedaaan yang besar dimana rataan hasil pendapatan tertinggi terdapat pada P4 sebesar Rp 678.850,00 dan yang terendah pada P0 yaitu sebesar Rp 547.150,00. Hal ini terjadi karena terdapat perbedaan bobot badan domba dan disebabkan kualitas pakan yang diberikan selama penelitian sehingga nilai pendapatan dari penjualan domba berbeda pada setiap ulangan. Ini sesuai dengan pernyataan Agus (1990) yang menyatakan bahwa, penerimaan pendapatan berasal dari penjualan barang, begitu juga pendapat dari Kadarsan (1995) yang menyatakan bahwa penerimaan perusahaan bersumber dari pemasaran atau penjualan hasil usaha seperti panen tanaman serta hasil olahannya serta panen dari peternakan serta hasil olahannya. 


\section{Analisa Laba/Rugi}

Analisis ekonomi atau laba rugi dilakukan untuk mengetahui apakah usaha tersebut rugi atau menguntungkan dengan cara menghitung selisih antara total hasil produksi dengan total biaya produksi. analisis laba-rugi setiap perlakuan memberi pengaruh yang berbeda-beda pada setiap total perlakuan. Perlakuan P0 mendapatkan keuntungan rata-rata Rp. 6.813,72/ekor, pada perlakuan P1 mendapatkan keuntungan rata-rata Rp. 119.750,78/ekor, pada perlakuan P2 mendapatkan keuntungan rata-rata Rp. 22.831,61/ekor, pada perlakuan P3 mendapatkan keuntungan rata-rata Rp. 34.618,46/ekor, pada perlakuan P4 mendapatkan keuntungan rata-rata Rp. 87.354,85/ekor.

Hasil yang diperoleh dapat dilihat keuntungan terendah dapat di lihat pada perlakuan P0 yaitu sebesar Rp. 6.813,72/ekor dan terbesar pada perlakuan P1 yaitu sebesar Rp. 119.750,78/ekor. Hal ini disebabkan pertambahan bobot badan domba sangat rendah dibandingkan dengan perlakuan lainnya. Hal ini juga disebabkan terdapat perbedaan harga dan kualitas pakan setiap perlakuan, sehingga total hasil produksi yaitu total penjualan ternak ditambah penjualan feses ternak memiliki nilai yang lebih tinggi dari pada total biaya produksi yaitu biaya pakan, biaya bibit domba, biaya obat-obatan, biaya peralatan dan sewa kandang serta biaya tenaga kerja. Hal ini sesuai dengan Murtidjo (1995) yaitu keuntungan dapat dicapai jika jumlah pendapatan yang diperoleh dari usaha tersebut lebih besar daripada jumlah pengeluarannya. Bila keuntungan dari suatu usaha semakin meningkat, maka secara ekonomis usaha tersebut layak dipertahankan atau ditingkatkan. Untuk memperoleh angka yang pasti mengenai keuntungan atau kerugian, yang harus dilakukan adalah pencatatan biaya. Tujuan pencatatan biaya juga agar peternak atau pengusaha dapat mengadakan evaluasi terhadap bidang usaha.

\section{Revenue cost ratio ( $\mathrm{R} / \mathrm{C}$ Ratio)}

Dilakukan dengan tujuan untuk melihat keuntungan relatif dalam sebuah usaha perikanan yang diperoleh dalam tahun terhadap biaya yang dikeluarkan dalam kegiatan usaha perikanam tersebut. Pada dasarnya, sebuah usaha dikatakan layak apabila nilai R/C lebih besar daripada 1 dikarenakan hal ini menggambarkan semakin tinggi nilai $\mathrm{R} / \mathrm{Cnya}$ maka tingkat keuntungan suatu usaha juga akan semakin tinggi.Analisis R/C Ratio digunakan dalam suatu usaha untuk mengetahui layak atau tidaknya usaha tersebut untuk 
dilakukan. R/C Ratio diperoleh dengan cara membagikan total hasil produksi dengan total biaya produksi . R/C Ratio terendah terdapat pada perlakuan P0 yaitu sebesar 1,01 dan tertinggi pada perlakuan P1 yaitu sebesar 1,22. Hal ini sesuai dengan pernyataan Soekartawi (1995) yang menyatakan bahwa suatu usaha dikatakan memberikan manfaat bila nilai $\mathrm{R} / \mathrm{C}$ Ratio $>1$. Semakin besar nilai R/C Ratio maka semakin efisien usaha tersebut dan sebaliknya semakin kecil nilai R/C Rationya, maka semakin tidak efisien usaha tersebut.

\section{Income Over Feed Cost (IOFC)}

IOFC didapat dengan cara menghitung nilai usaha peternakan yang didapat dari berat badan ternak (Bobot akhir-Bobot awal) dikali harga ternak/kg dikurangi dengan biaya pakan (total konsumsi dikali harga pakan perlakuan). IOFC tertinggi terdapat pada perlakuan P1 yaitu rata-rata sebesar Rp. 160.582,68/ekor hal ini dikarenakan bobot badan domba yang tinggi dikalikan harga jual per kilogram domba sehingga pendapatan penjualan domba lebih tinggi dari pada total biaya yang dikeluarkan untuk konsumsi domba tersebut dan juga dipengaruhi oleh tingkat konsumsi domba tersebut yang tinggi diikuti pertambahan bobot badan yang tinggi.

IOFC terendah terdapat pada perlakuan P0 yaitu rata-rata sebesar Rp. 47.545,62/ekor hal ini negatif dikarenakan bobot badan akhir domba sangat rendah dari perlakuan yang lain sehingga menyebabkan harga jual domba lebih rendah sehingga menyebabkan IOFC pada perlakuan P0 paling rendah dibandingkan dengan perlakuan lain. Hal ini sesuai dengan pernyataan Prawirokusumo (1990) bahwa IOFC merupakan barometer untuk melihat seberapa besar biaya pakan yang merupakan biaya terbesar dalam usaha penggemukan ternak. IOFC diperoleh dengan menghitung selisih pendapatan usaha peternakan dikurangi biaya pakan. Pendapatan merupakan perkalian antara produksi peternakan atau pertambahan bobot badan akibat perlakuan dengan harga jual ternak.

\section{KESIMPULAN}

Berdasarkan hasil penelitian dapat disimpulkan bahwa pemanfaatan tongkol jagung fermentasi starbio dalam pakan yang diberikan kepada domba jantan lokal lepas 
sapih mampu menambah keuntungan yang lebih besar terhadap nilai $\mathrm{R} / \mathrm{C}$ (Revenue Cost Ratio), dan IOFC (Income Over Feed Cost).

\section{DAFTAR PUSTAKA}

Agus. 1990. Analisis Pulang Pokok, UGM-Press, Yogyakarta.

Budiono. 1990. Ekonomi Mikro Edisi Sinopsis Pengantar Ilmu Ekonomi No.1 Edisi Kedua Cetakan ke II BEFE, Yogyakarta.

Kadarsan, H. 1995. Keuangan Pertanian dan Pemembiayaan Perusahaan Agribisnis. Cetakan ke Dua. PT Gramedia,Jakarta.

Murtidjo, B.A., 1995. Memelihara Domba. Kanisius, Yogyakarta.

Nuraini. I. 2003. Pengantar Ekonomi Mikro. Universitas Muhammadiyah, Malang.

Prawirokusumo, S., 1990. Ilmu Gizi Komparatif. UGM-Press, Yogyakarta.

Priyanto, D., M. Martawijaya, dan B. Setiadi.2004. Analisis Kelayakan Domba Lokal Pada Berbagai Skala Pemilikan. Prosiding Seminar Nasional Teknologi Peternakan dan Veteriner. Pusat Penelitian Dan Pengembangan Perternakan. Bogor.

Rasyaf, M. 1996. Pengelolaan Usaha Peternakan Ayam Pedaging. Penerbit Gramedia Pustaka Utama Jakarta.

Sarwono, B. 1996. Membuat Tempe dan Oncom. Penebar Swadaya, Jakarta.

Soekartawi. 1995. Dasar Penyusunan Evaluasi Proyek. Pustaka Sinar Harapan, Jakarta.

Suharno, B dan Nazaruddin, 1994. Ternak Komersial. Penebar Swadaya, Jakarta. 